\title{
Evaluation of Some Egyptian Barley Cultivars under Water Stress Conditions Using Drought Tolerance Indices and Multivariate Analysis
}

\author{
Samah A. Mariey * and Rania A. Khedr ** \\ *Barley Research Department and ${ }^{* *}$ Crop Physiologies Research Department, Field \\ Crops Research Institute, Agricultural Research Center, Cairo, Egypt
}

\begin{abstract}
THE PRESENT work was carried out in two separate field experiments of Sakha Research Farm during two growing seasons 2012/2013 and 2013/2014 to evaluate 15 barley cultivars under normal and water stress conditions. The results indicated that the cultivars Giza 2000, Giza 126 and Giza 131 had the highest performance for most of the studied traits under normal and water stress conditions. Also, these cultivars exhibited highly significant differences for all drought tolerance indices. First principal component analysis (PCA1) contributed $76.1 \%$ of the total variation with high positive values of grain yield under normal (Gyp), under water stress conditions (GYs), yield index (YI), stress tolerance index (STI), mean product (MP), geometric mean product (GMP) and harmonic mean (HM) indices while had negative values with tolerance index TOL and stress susceptibility index (SSI), but second PCA2 explained $23.0 \%$ of the total variability. Biplot diagram and cluster analysis divided the cultivars into four groups A, B, C and D based on the basis of PCA1 values, PCA2 values, GYp, GYs and selection drought tolerance indices. So, the cultivars which are found on A region, had high yield under both normal and water stress conditions, so we could consider these cultivars Giza 2000, Giza 126 and Giza 131 as water stress tolerant and we recommend them for using in breeding program for high yielding under normal and water stress conditions, and consider YI, STI, MP, GMP and HM as major and suitable indices for selecting cultivars with high yield at both environments.
\end{abstract}

Keywords: Hordeum vulgare l, Water stress, Correlation analysis, Drought tolerance indices, Principal components analysis, Biplot analysis, Cluster analysis

\section{Introduction}

Drought stress is the main factor that is limiting crop production in the world which affects around 40 to $60 \%$ of the world's agricultural lands (Shahryari and Mollasadeghi, 2011). Barley (Hordeum vulgare L.) is considered to be the best drought tolerant of the grain cereals, which is grown as the main annual rain-fed crop in low areas of North Africa and considered as a low risk crop. (Kilic et al., 2010). In Egypt, barley is considered a main crop which is grown in both rain fed and favorable irrigated soils of the Nile Valley, but drought stress causes reduction on barley grain yield production which is harshly affected by rain-fed area conditions (Forster et al., 2004).

Breeding for drought tolerance by using classic screening methods to evaluate the efficiently of large amount of genotypes was multifaceted, because of the absence of comprehensive information about the genetic mechanism of drought tolerance and grain yield under water stress conditions (Ashraf, 2010).

Drought tolerance indices are situated as mathematical models, which was used to measure the change in grain yield under stressed and non-stressed environments to screen the drought tolerant genotypes, which was based on drought tolerance or sensitive of genotypes (Mitra, 2001).

In barley, there are many reports use drought tolerance indices to distinguish high yielding cultivars under both non-stressed and stressed conditions using the most important indices such as Stress tolerance index (STI), Mean product (MP and Geometric mean product (GMP) which there were most suitable, many researchers such as Karami et al. (2005), Nazari and Pakniyat (2010), Zare (2012), Ajalli and Saleh (2013) and Subhani et al. (2015). 
Selection based on correlation is useful to find out the degree of general association only between any two measured characteristics, but selection based on a combination of indices which may offer a useful amount for improving drought tolerance of barley is better, Thus a well method such as biplot analysis is necessary to classify the superior cultivars for both non-irrigated stress and irrigated environments (Subhani et al., 2015).

The objectives of the present study were to determine the ability of drought tolerance indices to classify barley cultivars into sensitive and tolerant to water stress and to identify the association among tolerance indices through biplot analysis and cluster analysis.

\section{Materials and Methods}

Plant material and field experimental design

Fifteen barley cultivars namley Giza 123, Giza 124, Giza 125, Giza 126, Giza 127, Giza 128, Giza 129, Giza 130, Giza 131, Giza 132, Giza 133, Giza 134, Giza 135, Giza 136 and Giza 2000 were grown in two separate field experiments of Sakha Agricultural Research Station, Kafer EL-Sheikh, Egypt, during two growing seasons 2012/2013 and 2013/2014 under irrigated and non- irrigated water stress conditions.
Each cultivar was sown in six rows of $3.5 \mathrm{~m}$, spread out with $20 \mathrm{~cm}$ among rows in a randomized complete block design with three replications. The first experiment (normal condition) was irrigated twice after sowing, 45 days after sowing at tillering stage and 75 days after sowing at booting stage, the second experiment (water stress condition) was given just sowing irrigation. Sowing was done on Nov. $15^{\text {th }}$ in both seasons.

Ten agro-morphological parameters were measured in this study; total chlorophyll content (SPAD), flag leaf area $\left(\mathrm{cm}^{2}\right)$, days to maturity (days), peduncle length $(\mathrm{cm})$, spike length $(\mathrm{cm})$, number of tillers $\left(\mathrm{m}^{-2}\right), 1000$ grain weight $(\mathrm{g})$, biological yield $\left(\mathrm{t} \mathrm{ha}^{-1}\right)$, straw yield $\left(\mathrm{t} \mathrm{ha}^{-1}\right)$ and grain yield $\left(\mathrm{t} \mathrm{ha}^{-1}\right)$.

Soil samples were taken before land preparation in two depth from the soil surface; i.e. 0-15 $\mathrm{cm}$ and $15-30 \mathrm{~cm}$, the chemical properties of soil samples from the Sakha Field Experiments site during the two consecutive seasons, 2012/13 and 2013/14 as shown in Table1.

Maximum and minimum temperature, normal relative humidity and rainfall during the two seasons of barley crop at Sakha Agricultural Research Station are shown in Table 2.

TABLE 1. Chemical properties of soil samples from the Sakha Field Experiments site during the two consecutive seasons, 2012/13 and 2013/14

\begin{tabular}{lccccccccccc}
\hline Season & $\mathbf{p H}$ & $\mathbf{E C ~ d S m}^{-1}$ & $\mathbf{S P}$ & $\mathrm{CaCO}_{3}$ & $\mathrm{Ca}^{++}$ & $\mathbf{M g}^{++}$ & $\mathbf{N a}^{++}$ & $\mathbf{K}^{+}$ & $\mathbf{S O 4}$ & $\mathrm{Cl}$ & $\mathbf{H C O}_{3}$ \\
\hline $2012-2013$ & 7.1 & 3.0 & 7.6 & 0 & 4.6 & 2.5 & 14.8 & 0.2 & 18.2 & 11.2 & 5.5 \\
$2013-2014$ & 8 & 3.7 & 7.9 & 0 & 4.8 & 5.9 & 14.9 & 0.5 & 7.1 & 10.3 & 5.3 \\
\hline
\end{tabular}

TABLE 2. Maximum and minimum temperature, average relative humidity and rainfall during the growing seasons of barley crop at Sakha Agricultural Research Station

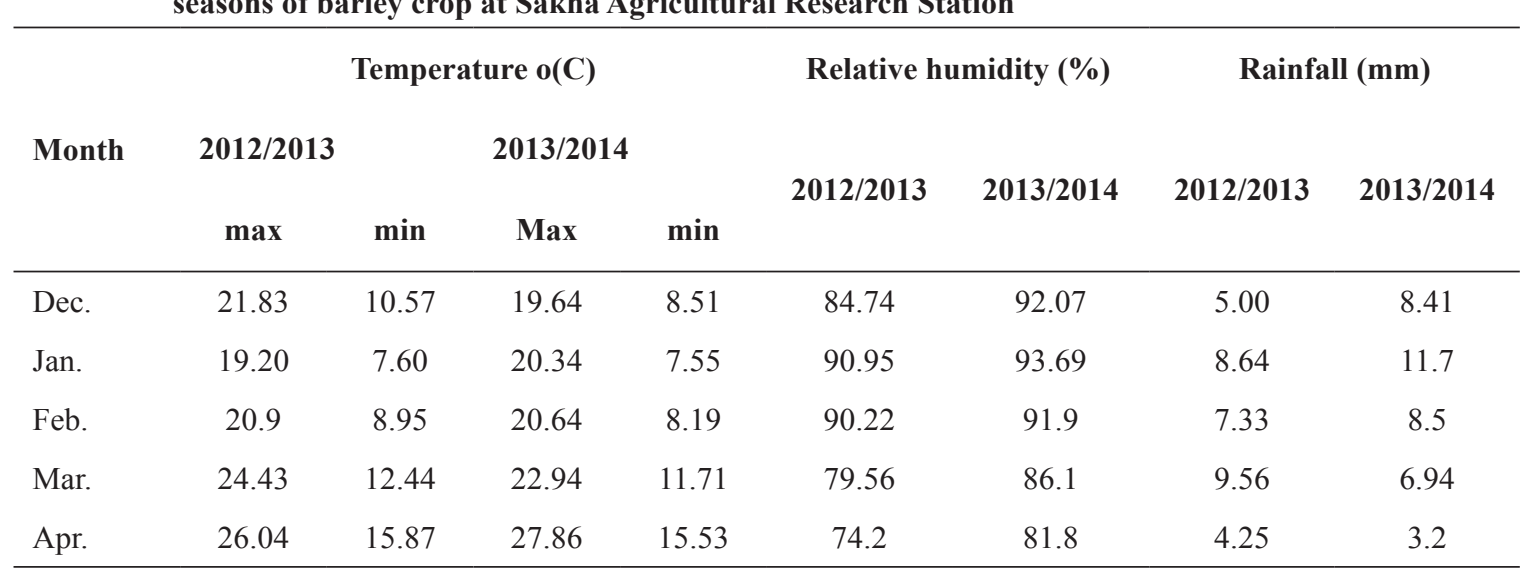


Data collection and statistical analysis

The combined data of measured morphological traits from the two seasons were analyzed based on the randomized complete block design (RCBD) with three replicates; all data collected were subjected to statistical analysis of variance according to Steel et al., 1997 with the help of statistical software MSTATC. Correlation coefficients among yield of irrigated (Yp) and non-irrigated stress (Ys), and stress indices were estimated according to the statistical techniques.

Drought tolerance indices were calculated according to the equations given in Table 3. Principal component and cluster analysis were analyzed using a computer software program Minitab v.12.

\section{Results and Discussion}

Analysis of variance of agro-morphological traits

High and significant differences were found among the 15 barley cultivars for ten studied traits, during the two growing seasons 2012/2013 and $2012 / 2014$ under both irrigated and non- irrigated stress conditions as shown in Table 4 . The interaction between cultivars and seasons, was significant and highly significant for all traits expect for leaf area, 1000 grain weight, biological yield, and straw yield were non- significant, and the interaction between treatment and cultivars was significant and highly significant for all traits. Regarding the interaction among cultivars, treatment and seasons, the data indicated that there were a significant and highly significant difference for all traits expect for chlorophyll content, leaf area and straw yield were non- significant. The results were similar to those obtained by El-Koliey and El-Hamid (2000), Shakhatreh et al. (2001), Samarah (2005), El-Sayed (2012), Fawzy et al. (2013), Haddadin, (2015) and Abu-El-Lail et al. (2016)

TABLE 3. Stress tolerance indices used for the evaluation of barley genotypes to drought tolerance

\begin{tabular}{|c|c|c|c|}
\hline No. & Stress tolerance indices & Equation & Reference \\
\hline 1 & Stress susceptibility index & $(\mathrm{SSI})=\left(1-Y_{S} / Y_{p}\right) /\left(1-Y_{S}^{-} / Y^{-} p\right)$ & Fischer and Maurer, (1978) \\
\hline 2 & Stress tolerance index & $\mathrm{STI})=Y p \times Y_{s} / Y^{-} p 2$ & Fernandez, (1992), \\
\hline 3 & Yield stability index & $(\mathrm{YSI})=\mathrm{Ys} / \mathrm{Yp}$ & Bouslama and Schapaugh, (1984) \\
\hline 4 & Yield index & $(\mathrm{YI})=Y_{S} / Y_{S}^{-}$ & Gavuzzi et al., (1997), \\
\hline 5 & Mean productivity & $(\mathrm{MP})=(\mathrm{Ys}+\mathrm{Yp}) / 2$ & Bouslama and Schapaugh,(1984) \\
\hline 6 & Geometric mea productivity & $(G M P)==\sqrt{ } \mathrm{Ys} \times \mathrm{Yp}$ & Sio-Se Mardeh et al., (2006) \\
\hline 7 & Harmonic Mean & $\mathrm{HM}=2\left(\mathrm{Ys}_{\mathrm{s}} \times \mathrm{Yp}\right) /\left(\mathrm{Ys}_{\mathrm{s}}+\mathrm{Yp}\right)$ & Rosielle \& Hamblin,( 1981) \\
\hline 8 & Tolerance index & $\mathrm{TOL}=Y p-Y_{s}$ & Rosielle and Hamblin(1981) \\
\hline
\end{tabular}

Where: Ys and Yp are the yields of cultivars evaluated under (stress) and (non-stress) conditions and $\mathrm{Y}^{-} \mathrm{s}$ and $\mathrm{Y}^{-} \mathrm{p}$ are the mean yields of all cultivars evaluated under stress and non-stress conditions, respectively.

TABLE 4. The analysis of variance for ten characteristics of 15 barley cultivars combined over the two 2012/2013 and 2013/2014 study seasons.

\begin{tabular}{|c|c|c|c|c|c|c|c|c|c|c|c|}
\hline Source & $\mathrm{Df}$ & MD & SL & PD & $\mathbf{C H}$ & $\mathbf{L A}$ & $\mathbf{T} / \mathbf{M}$ & $1000 \mathrm{~W}$ & GY & BY & SY \\
\hline \multirow{2}{*}{ Block } & & 3.74 & 0.25 & 0.09 & 0.03 & 1.44 & 194.4 & 0.28 & 0.07 & 1.2 & 0.84 \\
\hline & 2 & $\mathrm{Ns}$ & $\mathrm{Ns}$ & $\mathrm{Ns}$ & Ns & * & Ns & Ns & $\mathrm{Ns}$ & $\mathrm{Ns}$ & $\mathrm{Ns}$ \\
\hline \multicolumn{12}{|c|}{ Main effects } \\
\hline \multirow{5}{*}{$\begin{array}{l}\text { Cultivars } \\
\text { (V) } \\
\text { Seasons } \\
\text { (S) } \\
\text { Treatment } \\
\text { (T) }\end{array}$} & \multirow{2}{*}{18} & 24.89 & 12.3 & 83.98 & 115.5 & 16.4 & 1333704 & 207.55 & 72.7 & 169.5 & 40.53 \\
\hline & & $\begin{array}{c}* * \\
3875\end{array}$ & $* *$ & * & $\begin{array}{c}* * \\
0105\end{array}$ & $\begin{array}{c}* * \\
489\end{array}$ & $\begin{array}{c}* * \\
1092\end{array}$ & ** & $* *$ & $* *$ & $* *$ \\
\hline & 1 & $\begin{array}{c}38.15 \\
* *\end{array}$ & $\begin{array}{l}0.02 \\
\mathrm{Ns}\end{array}$ & $\begin{array}{c}0.85 \\
\mathrm{Ns}\end{array}$ & $\begin{array}{c}0.105 \\
\mathrm{Ns}\end{array}$ & $\begin{array}{c}4.89 \\
* *\end{array}$ & $\begin{array}{c}1092 \\
\mathrm{Ns}\end{array}$ & $\begin{array}{c}0.019 \\
\mathrm{Ns}\end{array}$ & 0.39 & $\begin{array}{c}1.80 \\
*\end{array}$ & $\begin{array}{c}4.37 \\
* *\end{array}$ \\
\hline & \multirow{2}{*}{1} & 1707.7 & 282.9 & 126007 & 1027 & 212.4 & 2279400 & 3647.2 & 754 & 18039 & 219.2 \\
\hline & & $* *$ & $* *$ & ns & $* *$ & $* *$ & $* *$ & $* *$ & $* *$ & $* *$ & $* *$ \\
\hline \multicolumn{12}{|c|}{ Interaction } \\
\hline \multirow{2}{*}{ VX S } & \multirow{2}{*}{18} & 6.48 & 0.88 & 3.89 & 2.72 & 0.55 & 2447.7 & 3.10 & 0.44 & 0.598 & 0.58 \\
\hline & & ** & $* *$ & ${ }^{* *}$ & ${ }^{*}{ }^{*}$ & $\mathrm{Ns}$ & $\stackrel{*}{*}$ & $\mathrm{Nss}_{3}$ & $* *$ & ${ }_{2} \mathrm{Ns}_{3}$ & $\mathrm{Ns}_{9}$ \\
\hline V XT & 18 & $\begin{array}{c}14.52 \\
* *\end{array}$ & $\begin{array}{l}2.44 \\
* *\end{array}$ & $\begin{array}{l}13.107 \\
* *\end{array}$ & $\begin{array}{c}11.52 \\
* *\end{array}$ & $\begin{array}{c}2.91 \\
* *\end{array}$ & $\begin{array}{l}2175.9 \\
* *\end{array}$ & $\begin{array}{c}46.33 \\
* *\end{array}$ & $\begin{array}{c}12.6 \\
* *\end{array}$ & $\begin{array}{c}29.31 \\
* *\end{array}$ & $\begin{array}{c}22.9 \\
* *\end{array}$ \\
\hline \multirow{2}{*}{$\mathrm{S} \times \mathrm{T}$} & \multirow{2}{*}{1} & 0.157 & 1.12 & 1.12 & 15.31 & 0.909 & 33580 & 1.66 & 1.84 & 0.363 & 0.884 \\
\hline & & $\mathrm{Ns}$ & $\stackrel{*}{*}$ & $\mathrm{Ns}_{4}$ & $* *$ & $\mathrm{Ns}$ & $\stackrel{*}{*}$ & $\mathrm{Ns}$ & $* *$ & $\mathrm{Ns}_{\mathrm{O}}$ & $\mathrm{Ns}$ \\
\hline VX SX T & 18 & $\begin{array}{l}4.11 \\
* *\end{array}$ & $\begin{array}{c}1.06 \\
* *\end{array}$ & $\begin{array}{c}2.84 \\
*\end{array}$ & $\begin{array}{l}1.38 \\
\mathrm{Ns}\end{array}$ & $\begin{array}{l}0.42 \\
\mathrm{Ns}\end{array}$ & $\begin{array}{c}1860.18 \\
* *\end{array}$ & $\begin{array}{l}1.19 \\
\mathrm{Ns}\end{array}$ & $\begin{array}{c}0.31 \\
*\end{array}$ & $\begin{array}{c}0.800 \\
*\end{array}$ & $\begin{array}{l}0.67 \\
\mathrm{Ns}\end{array}$ \\
\hline Error & 150 & 0.76 & 0.258 & 1.42 & 1.39 & 0.37 & 539.13 & 1.86 & 0.18 & 0.417 & 0.614 \\
\hline CV\% & & 0.75 & 6.27 & 4.65 & 2.64 & 7.88 & 5.25 & 2.72 & 6.03 & 5.02 & 13.51 \\
\hline LSD 0.05 & & 0.71 & 0.410 & 0.961 & 0.95 & 0.49 & 18.73 & 1.102 & 0.34 & 0.5211 & 0.631 \\
\hline
\end{tabular}

$\mathrm{MD}$ :days to maturity, SL : spike length, PD: peduncle length, $\mathrm{CH}$ : total chlorophyll content, LA :flag leaf area , TM : no.of tillers $\mathrm{m}^{-2}$ , 1000 W: 1000 grain weight, GY: grain yield, BY: biological yield , SY:straw yield , V : cultivars, T: treatment and, S: seasons . 
The combined mean performance for cultivars

The combined mean performance for barley cultivars under irrigated and non- irrigated water stress during the two seasons and their combined as shown in Tables 5\&6 indicted that among all the 15 Egyptian cultivars Giza 2000 had the highest values for some traits such as spike length with values $\left(9.7,10.3\right.$ and $\left.10.0 \mathrm{~cm}^{2}\right)$ number of tillers with values (766.0,763 and764.7 $\left.\mathrm{m}^{2}\right)$, biological yield with values $(20.8,21.4$ and 21.1 $\left.\mathrm{t} \mathrm{ha}^{-1}\right)$ and grain yield with values $(13.3,13.9$ and 13.6 $\mathrm{t} \mathrm{ha}^{-1}$ ), in both seasons and their combined respectively, followed by Giza 131 which had the heights values for total chlorophyll content with values (49.1,48.6 and 48.9 SPAD), leaf area with values ( 9.6,9.4 and 9.6cm) and peduncle length with values (32.2,33.2 and 32.7)in both two seasons and their combined respectively, and the Egyptian cultivar Giza 126 gave the highest values for 1000 grain with values $(54.8,55.1$ and
$54.9 \mathrm{~g})$ and straw yield with values ( 8.9, 10.1 and 9.5 tha $^{-1}$ ) in both seasons and their combined respectively

On the other hand, from the pooled means performance for barley cultivars under irrigated and non- irrigated water stress during the two seasons and their combined as shown in Tables $5 \& 6$, the results indicated that among all the 15 Egyptian cultivars the Giza 129 cultivar had the lowest values for the some traits such as total chlorophyll content with values $(39.0,38.5$ and 38.7 SPAD), days to $50 \%$ maturity $(118.2,117.7$ and 117.9 days), number of tiller $(312.1,297.5$ and $\left.304.7 \mathrm{~m}^{-2}\right)$ and grain yield with values $(4.5,4.7$ and $\left.4.6 \mathrm{tha}^{-1}\right)$ in both seasons and their combined respectively. Likewise Giza 132 gave the lowest values for peduncle length, spike length; 1000 grain and biological yield in both seasons and their combined.

TABLE 5. Combined mean performance of the total chlorophyll content, flag leaf area, days to maturity, peduncle length and spike length, under irrigated and non-irrigated water during 2012/2013 and 2013/2014 seasons

\begin{tabular}{|c|c|c|c|c|c|c|c|c|c|c|c|c|c|c|c|}
\hline \multirow[t]{2}{*}{ V } & \multicolumn{3}{|c|}{$\begin{array}{l}\text { Total chlorophyll } \\
\text { (SPAD) }\end{array}$} & \multicolumn{3}{|c|}{$\begin{array}{l}\text { Flag leaf area } \\
\quad(\mathrm{cm})^{2}\end{array}$} & \multicolumn{3}{|c|}{$\begin{array}{l}\text { Days to maturity } \\
\text { (days) }\end{array}$} & \multicolumn{2}{|c|}{$\begin{array}{l}\text { Peduncle length } \\
(\mathrm{cm})^{2}\end{array}$} & \multicolumn{4}{|c|}{$\begin{array}{l}\text { Spike length } \\
(\mathrm{cm})^{2}\end{array}$} \\
\hline & Ses1 & Ses2 & Comb. & Ses1 & Ses2 & Comb. & Ses1 & Ses2 & Comb. & Ses1 & Ses2 & Comb. & Ses1 & Ses2 & Comb. \\
\hline G123 & 47.1 & 45.6 & 46.3 & 9.2 & 8.7 & 9.0 & 112.0 & 112.5 & 112.3 & 28.5 & 28.2 & 28.3 & 8.7 & 9.0 & 8.8 \\
\hline G 124 & 44.7 & 44.6 & 44.7 & 8.2 & 8.6 & 8.4 & 114.0 & 116.3 & 115.2 & 25.5 & 23.0 & 24.3 & 7.7 & 6.5 & 7.1 \\
\hline G 125 & 46.7 & 48.7 & 47.7 & 8.3 & 9.0 & 8.7 & 114.7 & 116.2 & 115.4 & 24.8 & 24.9 & 24.9 & 9.5 & 9.3 & 9.4 \\
\hline G 126 & 48.0 & 46.8 & 47.4 & 7.3 & 7.8 & 7.6 & 112.5 & 112.8 & 112.7 & 24.5 & 24.5 & 24.5 & 8.3 & 8.7 & 8.5 \\
\hline G 127 & 41.1 & 42.1 & 41.6 & 5.2 & 5.6 & 5.4 & 116.7 & 116.8 & 116.8 & 23.3 & 24.1 & 23.7 & 7.2 & 7.7 & 7.4 \\
\hline G 128 & 43.8 & 44.6 & 44.2 & 5.9 & 6.5 & 6.2 & 115.8 & 115.5 & 115.7 & 22.8 & 23.0 & 22.9 & 8.7 & 8.8 & 8.8 \\
\hline G 129 & 39.0 & 38.5 & 38.7 & 5.9 & 6.8 & 6.3 & 118.2 & 117.7 & 117.9 & 24.5 & 24.4 & 24.4 & 7.8 & 7.3 & 7.6 \\
\hline G130 & 45.9 & 46.2 & 46.0 & 7.0 & 7.1 & 7.0 & 116.2 & 115.2 & 115.7 & 25.0 & 25.8 & 25.4 & 6.8 & 6.8 & 6.8 \\
\hline G 131 & 49.1 & 48.6 & 48.9 & 9.6 & 9.4 & 9.5 & 116.0 & 116.7 & 116.3 & 32.2 & 33.2 & 32.7 & 9.3 & 9.8 & 9.6 \\
\hline G 132 & 41.6 & 41.1 & 41.3 & 8.1 & 7.7 & 7.9 & 115.3 & 116.0 & 115.7 & 22.3 & 23.1 & 22.7 & 7.0 & 6.5 & 6.8 \\
\hline G133 & 44.5 & 44.7 & 44.6 & 7.7 & 8.1 & 7.9 & 117.3 & 116.5 & 116.9 & 25.3 & 26.3 & 25.8 & 7.7 & 7.3 & 7.1 \\
\hline G 134 & 45.8 & 45.2 & 45.5 & 5.8 & 5.7 & 5.8 & 114.3 & 116.2 & 115.3 & 28.0 & 25.8 & 26.9 & 8.2 & 8.1 & 8.1 \\
\hline G135 & 44.7 & 45.1 & 44.9 & 7.8 & 8.0 & 7.9 & 112.3 & 117.2 & 114.8 & 22.8 & 21.2 & 22.0 & 7.2 & 7.2 & 7.2 \\
\hline G 136 & 47.7 & 48.2 & 48.1 & 8.5 & 8.9 & 8.7 & 115.7 & 117.2 & 116.4 & 24.0 & 25.1 & 24.6 & 8.8 & 8.5 & 8.7 \\
\hline G2000 & 48.1 & 48.3 & 48.2 & 8.7 & 9.2 & 8.9 & 113.5 & 116.2 & 114.8 & 26.8 & 26.6 & 26.7 & 9.7 & 10.3 & 10.0 \\
\hline Average & 45.2 & 45.2 & 45.2 & 7.5 & 7.8 & 7.7 & 115.0 & 115.9 & 115.4 & 25.4 & 25.3 & 25.3 & 8.2 & 8.1 & 8.1 \\
\hline C.V\% & 2.08 & 3.104 & 2.64 & 5.03 & 6.30 & 7.8 & 0.72 & 0.78 & 0.75 & 3.38 & 5.511 & 4.65 & 6.21 & 6.34 & 6.27 \\
\hline L.S.D & 1.06 & 1.59 & 0.95 & 1.01 & 0.57 & 0.49 & 0.95 & 1.05 & 0.704 & 0.99 & 1.611 & 0.96 & 0.57 & 0.59 & 0.41 \\
\hline
\end{tabular}


TABLE 6. Combined means performance of the no. tillers $\mathrm{m}^{-2}, 1000$ grain weight, biological yield $\left(\right.$ tha $^{-1}$, straw yield $\left(t\right.$ ha- $\left.{ }^{-1}\right)$ and grain yield (tha ${ }^{-1)}$, under irrigated and non-irrigated stress during 2012/2013 and 2013/2014 seasons

\begin{tabular}{|c|c|c|c|c|c|c|c|c|c|c|c|c|c|c|c|}
\hline \multirow[t]{2}{*}{ V } & \multicolumn{3}{|c|}{$\begin{array}{l}\text { No. of Tillers } \\
\mathrm{m}^{-2}\end{array}$} & \multicolumn{3}{|c|}{ 1000-grain weight (g) } & \multicolumn{3}{|c|}{$\begin{array}{c}\text { Biological yield } \\
\left(\mathrm{t} \mathrm{ha}^{-1}\right)\end{array}$} & \multicolumn{3}{|c|}{$\begin{array}{l}\text { Straw yield } \\
\left(\mathrm{t} \mathrm{ha}^{-1}\right)\end{array}$} & \multicolumn{3}{|c|}{$\begin{array}{l}\text { Grain yield } \\
\left(\mathrm{t} \mathrm{ha} \mathrm{h}^{-1}\right)\end{array}$} \\
\hline & Ses1 & Ses2 & Com. & Ses1 & Ses2 & Com & Ses1 & Ses2 & Com & Ses1 & Ses2 & Com & Ses1 & Ses2 & Com \\
\hline G123 & 468.3 & 501.5 & 484.9 & 58.8 & 58.0 & 58.4 & 16.0 & 15.8 & 15.9 & 8.3 & 8.1 & 8.2 & 7.7 & 7.7 & 7.7 \\
\hline G 124 & 389.2 & 407.2 & 398.2 & 46.1 & 47.4 & 46.7 & 14.4 & 15.1 & 14.7 & 8.0 & 8.9 & 8.4 & 6.5 & 6.2 & 6.3 \\
\hline G 125 & 463.8 & 428.3 & 446.0 & 51.2 & 52.5 & 51.8 & 12.6 & 12.7 & 12.6 & 5.0 & 5.6 & 5.3 & 7.6 & 7.1 & 7.3 \\
\hline G 126 & 503.3 & 499.2 & 501.3 & 54.8 & 55.1 & 54.9 & 19.7 & 20.3 & 20.0 & 8.9 & 10.1 & 9.5 & 10.7 & 10.2 & 10.5 \\
\hline G 127 & 499.2 & 449.3 & 474.3 & 50.1 & 49.4 & 49.7 & 10.5 & 10.2 & 10.4 & 4.5 & 4.0 & 4.2 & 6.0 & 6.2 & 6.1 \\
\hline G 128 & 553.8 & 573.3 & 563.5 & 49.3 & 49.7 & 49.5 & 9.5 & 10.6 & 10.1 & 2.2 & 3.2 & 2.7 & 7.3 & 7.3 & 7.3 \\
\hline G129 & 312.1 & 297.5 & 304.8 & 50.7 & 51.6 & 51.2 & 10.6 & 11.0 & 10.8 & 6.2 & 6.2 & 6.2 & 4.5 & 4.7 & 4.6 \\
\hline G130 & 400.0 & 395.4 & 397.5 & 47.6 & 48.0 & 47.8 & 12.8 & 12.1 & 12.4 & 5.5 & 5.5 & 5.5 & 7.2 & 6.7 & 6.9 \\
\hline G 131 & 497.5 & 449.2 & 473.3 & 57.9 & 58.1 & 58.0 & 17.9 & 18.3 & 18.1 & 7.2 & 7.1 & 7.2 & 10.7 & 11.2 & 10.9 \\
\hline G 132 & 330.0 & 344.2 & 337.1 & 42.0 & 41.1 & 41.6 & 8.2 & 8.9 & 8.5 & 4.0 & 4.6 & 4.3 & 4.2 & 4.3 & 4.2 \\
\hline G133 & 435.8 & 479.2 & 457.5 & 47.9 & 48.1 & 48.0 & 13.1 & 12.8 & 13.0 & 4.9 & 5.3 & 5.1 & 8.3 & 7.6 & 7.9 \\
\hline G 134 & 422.5 & 450.0 & 436.3 & 50.4 & 50.2 & 50.3 & 12.3 & 12.5 & 12.4 & 4.8 & 5.0 & 4.9 & 7.5 & 7.5 & 7.5 \\
\hline G 135 & 322.3 & 330.8 & 326.6 & 45.7 & 44.9 & 45.3 & 10.4 & 10.5 & 10.4 & 3.8 & 4.2 & 4.0 & 6.5 & 6.3 & 6.4 \\
\hline G 136 & 396.7 & 441.7 & 419.2 & 47.6 & 47.9 & 47.7 & 13.2 & 12.8 & 13.0 & 7.4 & 7.8 & 7.6 & 5.7 & 5.0 & 5.4 \\
\hline G 2000 & 766.0 & 763.3 & 764.7 & 54.6 & 53.7 & 54.1 & 20.8 & 21.4 & 21.1 & 7.6 & 7.5 & 7.5 & 13.3 & 13.9 & 13.6 \\
\hline Average & 450.7 & 454.0 & 452.3 & 50.3 & 50.4 & 50.3 & 13.5 & 13.7 & 13.6 & 5.9 & 6.2 & 6.0 & 7.6 & 7.5 & 7.5 \\
\hline C.V\% & 4.95 & 5.56 & 5.25 & 2.24 & 3.13 & 2.72 & 4.35 & 5.26 & 5.62 & 12.17 & 14.53 & 13.51 & 5.47 & 6.45 & 6.03 \\
\hline L.S.D & 25.06 & 28.24 & 18.42 & 1.29 & 1.81 & 1.12 & 0.64 & 0.83 & 0.52 & 0.76 & 0.99 & 0.63 & 0.447 & 0.52 & 0.53 \\
\hline
\end{tabular}

From above data we could consider that the Egyptian cultivars Giza 126, Giza 2000 and Giza 131 as water stress tolerant cultivars while Giza 132 and Giza 129 could be considered as water stress sensitive cultivars, so we could use those cultivars in breeding programs for water stress conditions. However, we could consider that the cultivars Giza 123, Giza 125, Giza128, Giza130, Giza133 and Giza 134 as moderated tolerant cultivars under water stress conditions. The results were in good harmony with those of Amer (2011), Abd-El-Rahman et al. (2012), El-Sayed (2012), Fawzy et al. (2013), El-Seidy et al. (2013), ElBawab et al. (2014) and Haddadin (2015).

Drought tolerance indices for water stress tolerance

The combined data of the two growing seasons 2012/013 and 2013/014 demonstrated the mean grain yield of barley cultivars as shown in Table 7. The maximum values of grain yield were found for the cultivars Giza 2000, Giza 126 and Giza 131 were $\left(14.13,13.16\right.$ and $11.53 \mathrm{t} \mathrm{ha}^{-1}$ ) under normal condition respectively, and were (9.60, 9. 66 and $\left.9.42 \mathrm{t} \mathrm{ha}^{-1}\right)$ under non- irrigated condition respectively, while the minimum values under normal and stress conditions were obtained by the cultivars Giza 132 and Giza 129 with values of $\left(4.57,5.11\right.$ and $\left.2.08,3.11 \mathrm{t} \mathrm{ha}^{-1}\right)$ respectively. Therefore, the cultivars Giza 2000,
Giza 126 and Giza 131 had the best performance for grain yield under irrigated and non-irrigated stress conditions; also these cultivars exhibited highly significant differences for all the drought tolerance indices.

Results in Table 7 indicated that the highest values of yield index (YI),Stress tolerance index (STI), Mean product (MP), Geometric mean product (GMP) and Harmonic Mean (HM) indices were performed by the cultivars Giza 2000, Giza 131 and Giza 126 which had the maximum grain yield under normal GYp and stress condition GYs. Whereas the lowest values of YI, STI, MP, GMP and HM indices were obtained by Giza 132 and Giza 129 which had the minimum grain yield values under normal and stress conditions, and all the remained cultivars had moderate values of YI, STI, MP, GMP and HM indices. These results are similar to those by Fernandez (1992) who used MP, GMP, YI and STI indices for screening drought tolerant and high yielding genotypes in both conditions and found that these indices were able to discriminate cultivars into four groups, A group, including cultivars with high yield in both conditions, group B include cultivars with good performance only in normal condition, group $\mathrm{C}$ include cultivars with good performance only in stress conditions, and group D include cultivars with poor performance in both conditions. Thus, 
the cultivars which have high values of MP, GMP, YI, HM and STI indices were considered as tolerant cultivars under irrigated and nonirrigated water stress and also we could consider that these indices are more suitable indices to isolated cultivars to tolerant, sensitive, moderate tolerant and moderate sensitive under irrigated and non-irrigated water stress. These results are corroborated with the findings of Bouslama \& Schapaugh (1984), Gavuzzi et al. (1997), Karami et al. (2005), Nazari and Pakniyat (2010), Zare (2012), Ajalli \& Salehi (2013) and Subhani et al. (2015).

TABLE 7. water stress tolerance indices of the 15 barley cultivars under irrigated and non- irrigated condition during two cropping seasons 2012/2013 and 2013/2014

\begin{tabular}{lllllllllll}
\hline Cultivars & GYp & GYs & YI & STI & MP & GMP & HM & SSI & TOL & YSI \\
\hline Giza 123 & 9.71 & 6.67 & 1.14 & 0.78 & 8.19 & 8.05 & 7.91 & 0.87 & 3.05 & 0.69 \\
Giza 124 & 7.90 & 4.77 & 0.81 & 0.46 & 6.33 & 6.14 & 5.95 & 1.10 & 3.13 & 0.60 \\
Giza125 & 8.32 & 6.35 & 1.08 & 0.64 & 7.34 & 7.27 & 7.20 & 0.66 & 1.97 & 0.76 \\
Giza 126 & 11.53 & 9.42 & 1.61 & 1.31 & 10.47 & 10.42 & 10.36 & 0.51 & 1.11 & 0.82 \\
Giza 127 & 7.68 & 4.57 & 0.78 & 0.42 & 6.13 & 5.92 & 5.73 & 1.13 & 3.11 & 0.59 \\
Giza 128 & 9.82 & 4.84 & 0.83 & 0.57 & 7.33 & 6.89 & 6.48 & 1.09 & 2.01 & 0.61 \\
Giza 129 & 5.11 & 3.11 & 0.53 & 0.19 & 4.11 & 3.98 & 3.86 & 1.49 & 4.98 & 0.49 \\
Giza 130 & 9.15 & 5.72 & 0.98 & 0.63 & 7.43 & 7.23 & 7.04 & 1.04 & 3.43 & 0.62 \\
Giza 131 & 12.16 & 9.66 & 1.65 & 1.54 & 11.41 & 11.27 & 11.14 & 0.74 & 1.50 & 0.73 \\
Giza 132 & 4.57 & 2.08 & 0.36 & 0.11 & 3.32 & 3.08 & 2.86 & 1.51 & 5.62 & 0.46 \\
Giza 133 & 10.72 & 5.10 & 0.87 & 0.66 & 7.91 & 7.40 & 6.92 & 1.46 & 2.48 & 0.49 \\
Giza 134 & 9.71 & 5.33 & 0.91 & 0.63 & 7.52 & 7.19 & 6.88 & 1.25 & 4.38 & 0.55 \\
Giza 135 & 7.64 & 5.25 & 0.90 & 0.49 & 6.44 & 6.33 & 6.22 & 0.87 & 2.40 & 0.69 \\
Giza 136 & 7.21 & 5.50 & 0.94 & 0.48 & 6.35 & 6.30 & 6.24 & 0.89 & 1.71 & 0.76 \\
Giza2000 & 14.13 & 9.60 & 1.64 & 1.64 & 11.86 & 11.65 & 11.43 & 0.66 & 1.54 & 0.79 \\
\hline
\end{tabular}

For Stress susceptibility index (SSI) and Tolerance index (TOL) indices, the results which were obtained from Table 7 indicted that the highest values of TOL and SSI were performed by Giza 132 and Giza 129 , while the lowest values of TOL and SSI were found by cultivars Giza 2000, Giza 131 and Giza 126. Concerning, yield stability index (YSI) the maximum values were recorded for Giza 2000, Giza 131 and Giza 126 and the lowest YSI values were recorded by Giza 132 and Giza 129. Therefore, from the results in Table 7, we could consider that the cultivars which had the lowest values of TOL and SSI and high values of YSI, as tolerant cultivars, while the cultivars with low values of TOL and SSI and high YSI values could be considered as sensitive cultivars. Therefor, the TOL, SSI and YSI indices were found to be more useful indices in discriminating water stress tolerant and sensitive cultivars, These results are corroborated with the findings of those obtained by Fernandez (1992), Blum (1996), Guendouz et al. (2012), Haddadin et al. (2013), Sultan et al. (2013), Haddadin( 2015) and Subhani et al. (2015).

As a result, based on MP, GMP, YI, HM and STI indices values, we could consider that Egypt. J. Sus. Agric. Sci . 43, No.2 (2017)
Egyptian cultivars (Giza 2000, Giza 131 and Giza 126) as tolerant cultivars and both of Giza 132 and Giza 129 as sensitive cultivars and the other cultivars as moderate tolerant and moderate sensitive.

\section{Correlation analysis for water stress tolerance}

The correlation coefficients (Table 8) between drought tolerance indices and, grain yield under both normal and stress conditions GYp and GYs both showed positive and high significant correlation with the Yield index (YI), Stress tolerance index (STI), mean productivity (MP), geometry mean of productivity (GMP) and harmonic mean (HM). These results are consistent with the results obtained by Nazari \& Pakniyat (2010), Sharafi et al. ( 2013) and Dorostkar et al. (2016) which supposed that the best suitable indices to select stress tolerant cultivars, is the index which has quite high correlation with grain yield in both stressed and non-stressed conditions. Therefore, from our results through the assessment of correlation rate between grain yield and water stress tolerance indices in both conditions, we could consider that the Yield index (YI), Stress tolerance index (STI), mean productivity (MP), geometry mean of 
productivity (GMP) and harmonic mean (HM), as major and suitable indices for selecting cultivars with high yield under irrigated and non- irrigated water stress conditions.

\section{Multivariate analysis}

Principal component analysis (PCA)

From the biplot analysis we could identify the highst cultivars for both non-irrigated and irrigated environments stress since the biplot analysis was used to determine the association between all the traits at once and based on the principal component analysis of the first principal component analysis (PCA1) and second principal component analysis PCA2, which contained about $99.1 \%$ of the total variation (Table 9), The first principal component analysis (PCA1) clarified $76.1 \%$ of the variation with positive values for GYp, GYs, MP, GMP, HM.STI, YI and YSI and negative values with TOL and SSI as shown in Table 9. So the cultivars which had high and positive value of this component will be high yielding in non-irrigated and irrigated stress conditions as shown in Fig. 1, therefore the PCA1 can be named as the yield impending and water deficiency tolerance

The second principal component PCA2 clarified $23.0 \%$ of the total variability which was positively correlated with GYs, YSI, YS, MP, STI and HM, and negatively correlated with GYp, SSI, TOL and GMP as shown in Table 9. Therefore, the second principal component can be described as stress sensitive component, which could discriminate the tolerant cultivars from sensitive cultivars.

So the selection of cultivars which had high PCA1 and PCA2 were more suitable for irrigated

TABLE 8. Correlation coefficients between drought tolerance indices and GYp and GYs of 15 barley cultivars under irrigated and non-irrigated condition during two cropping seasons 2012/2013 and 2013/2014

\begin{tabular}{lccccccccc}
\hline Trait & GYp & GYs & YI & STI & MP & GMP & HM & SSI & TOL \\
\hline GYs & $0.894^{* *}$ & & & & & & & & \\
YI & $0.894^{* *}$ & $1.000^{* *}$ & & & & & & & \\
STI & $0.938^{* *}$ & $0.970^{* *}$ & $0.971^{* *}$ & & & & & & \\
MP & $0.978^{* *}$ & $0.968^{* *}$ & $0.968^{* *}$ & $0.979^{* *}$ & & & & & \\
GMP & $0.965^{* *}$ & $0.981^{* *}$ & $0.981^{* *}$ & $0.982^{* *}$ & $0.998^{* *}$ & & & & \\
HM & $0.950^{* *}$ & $0.989^{* *}$ & $0.989^{* *}$ & $0.983^{* *}$ & $0.994^{* *}$ & $0.999^{* *}$ & & & \\
SSI & $-0.33 \mathrm{~ns}$ & $-0.688^{* *}$ & $-0.687^{*}$ & $-0.521^{*}$ & $-0.497 \mathrm{~ns}$ & $-0.543^{*}$ & $-0.583^{*}$ & & \\
TOL & $0.552^{*}$ & $0.120 \mathrm{~ns}$ & $0.120 \mathrm{~ns}$ & $0.273 \mathrm{~ns}$ & $0.364 \mathrm{~ns}$ & $0.312 \mathrm{~ns}$ & $0.264 \mathrm{~ns}$ & $0.587^{*}$ & \\
YSI & $0.312 \mathrm{~ns}$ & $0.688^{* *}$ & $0.687^{* *}$ & $0.522^{*}$ & $0.497 \mathrm{~ns}$ & $0.542 *$ & $0.582^{*}$ & $-1.000^{* *}$ & $-0.588^{*}$ \\
\hline
\end{tabular}

Ns, * and ** non-significant and significant at the 0.05 and 0.01 levels of probability, respectively GYs - Grain yield under stressed environment, GYp Grain yield under normal environment - YI: Yield index STI: Stress tolerance index MP: Mean product; GMP: Geometric mean product; HM: Harmonic Mean: TOL: Tolerance; SSI: Stress susceptibility index and YSI: Yield stability index

TABLE 9. Principal component analysis for Yp, Ys and stress tolerance indices of 15 barley genotypes

\begin{tabular}{lcccc}
\hline Traits & PCA1 & PCA2 & PCA3 & PCA4 \\
\hline Gyp & 0.333 & -0.259 & -0.163 & 0.084 \\
GYs & 0.362 & 0.035 & 0.113 & 0.265 \\
YSI & 0.362 & 0.034 & 0.121 & 0.280 \\
YS & 0.354 & 0.087 & 0.565 & -0.738 \\
TOL & -0.356 & -0.128 & -0.040 & 0.173 \\
MP & 0.359 & 0.093 & -0.011 & 0.152 \\
STI & 0.361 & 0.060 & 0.017 & 0.144 \\
SSI & -0.237 & -0.493 & 0.390 & 0.202 \\
GMP & 0.064 & -0.639 & -0.578 & -0.337 \\
HM & 0.237 & 0.493 & -0.372 & -0.267 \\
\hline Eigenvalue & 7.6 & 2.29 & 0.083 & 0.006 \\
Variance \% & 76.1 & 23.0 & 9.0 & 1.0 \\
Cumulative variance $(\%)$ & 76.1 & 99 & 99 & 100 \\
\hline
\end{tabular}


and non- irrigated stress conditions. Therefore, the cultivars Giza 126, Giza 131 and Giza 2000 with high PCA1 and PAC2 will be more suitable cultivars for stress and irrigated conditions (Fig. 1) and both of Giza 129 and Giza 132 with low PCA1 and PAC2 were identified as highly water stress sensitive cultivars with low yield stability. These results are in agreement with the finding of Zare (2012), Muhammad et al. (2012), Ajalli \& Salehi (2013), Sharafi et al. (2013) and Dorostkar et al. (2016).

\section{Cluster analysis}

Cluster analysis based on GYp, GYs and selection drought stress tolerance indices were performed in Fig. 2 and was done by parallel matrix based on Euclidean distance measurement and non-weighted paired group method using mathematics average (UPGMA). The cluster analysis was performed on YI, GMP, MP, HM and STI indices where these were the most important criteria that were confirmed by correlation coefficients and principal component analysis, and were totally in agreement with agro- morphological traits (Tables 5\&6 ) and drought tolerant indices (Table 7). So the results of cluster analysis indicated that all cultivars were classified into four groups: A group (T) include the water stress tolerance cultivars Giza 126, Giza 131 and Giza 2000), D group (S) include the water stress sensitive cultivars together Giza 129 and Giza 132), B group include the moderate tolerance water stress cultivars (MT) include Giza123, Giza125, Giza 128, Giza 134, Giza 130 and Giza 135 and $\mathrm{C}$ group moderate sensitive water stress cultivars (MS) include Giza 124, Giza 127, Giza 135 and Giza 136 cultivars. These results were in a good harmony with Sharafi et al. (2013), Subhani et al. (2015) and Dorostkar et al. (2016) who used cluster analysis for grouping barley genotypes based on drought stress tolerance indices.

\section{Acknowledgement}

The authors are thankful to Barley Research Department staff, Agricultural Research Center, for the facilities provided and thankful to Ammar El-Akhader for his help.

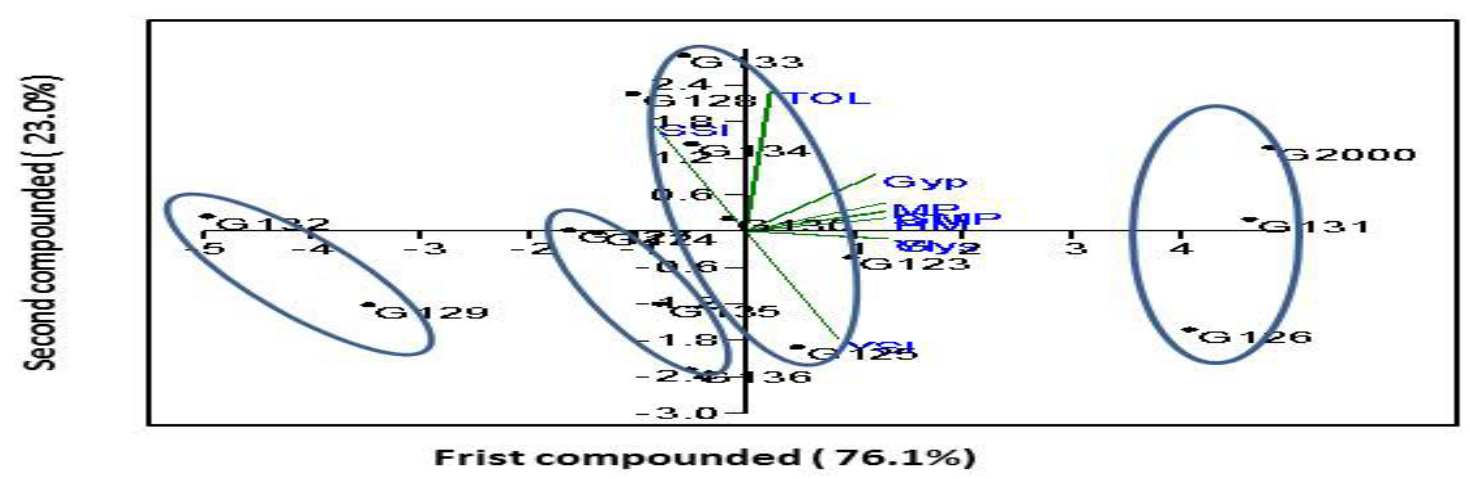

Fig. 1 Biplot analysis of water stress tolerance indices between PCA1 and PCA2

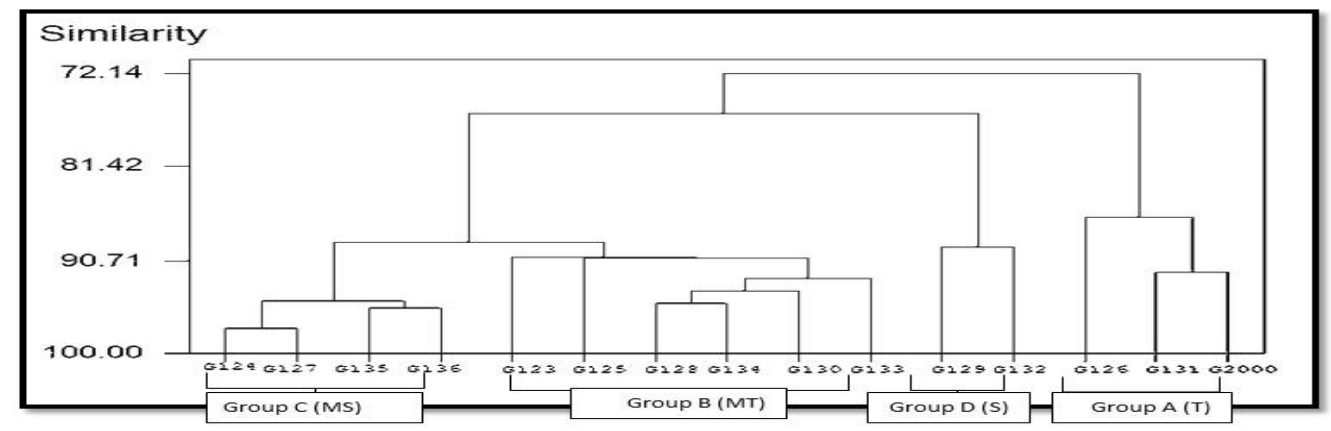

Fig.2. dendrogram describing genetic relationships among the 15 Egyptian barley cultivars based on water stress indices under the two locations over the two seasons 


\section{References}

Abd-El-Rahman, M.F.S., Khalil F.A.F. and Anton N.A. (2012) Effect of irrigation scheduling and nitrogen fertilization on barley yield and water use efficiency. J. Soil Sci. Agric. Eng., Mansoura Univ., 3, 633-645.

Abu-El-Lail, F.F.B, Hamam, K.A, Kheiralla, K.A. and El-Hifny, M.Z (2016) Evaluation of twenty barley genotypes for drought tolerance under sandy clay soil. Egypt. J. Agron., 38, 173-187.

Ajalli, J. and Salehi, M. (2013) Evaluation of drought stress indices in barley (Hordeum vulgare L.). American-Eurasian J. Agric. and Environ. Sci. 13, 134-138.

Amer, Kh. A. (2011) Genetic Analysis of yield and its components under normal and drought conditions in some barley crosses. Egypt. J. Plant Breed, 15, 65-79.

Ashraf, M. (2010) Inducing drought tolerance in plants. Recent Advances, Biotech. Adv., 28, 169-183.

Blum, A. (1996) Crop responses to drought and the interpretation of adaptation. Plant Growth Regul., 20, 135-148.

Bouslama M. and Schapaugh, W.T. (1984) Evaluation of three screening techniques for heat and drought tolerance. Crop Science, 24, 933-937.

Dorostkar, S., Paknyiat, H., Kordshooli, M.A., Massumeh, R.G., Aliakbari, N.S. and Valiloo, R. (2016) Evaluation of several drought tolerance criteria in cultivated cultivars of barley (Hordeum vulgare l.) and their relationships with yield reduction. Science Research, 4, 26-32.

El-Bawab, A.M.O., Anton, N.A., Ashmawy, H.A., Seham M. Mohamed and Abd El-Rahman, M.F.S. (2014) Evaluation of three barley cultivars under water deficit conditions of new reclaimed lands. Egypt. J. Plant Breed, 18, 687 - 699

El-Koliey, M.M. and El-Hami, M.A. (2000) Tolerance of some barley cultivars to drought conditions. Assiut J. Agric. Sci., 31 (4), 247-267.

El-Sayed, M.M.A. (2012) Genetical studies on some barley genotypes and its tolerance to drought. $P h$. D. Thesis. Fac., Agric., Tanta Univ., Egypt.

El-Seidy, E.H.E., Amer, Kh. A., El-Gammaal, A.A. and El-Shawy, E.E. (2013) Growth analysis and yield response of barley as affected by irrigation regimes. Egypt. J. Agron., 35, 1-19.
Fawzy F.S., Abd El-Mohsen, A.A, and Al-Soudan, I.H. (2013) Parametric Statistical Methods for Evaluating Barley Genotypes in Multi-environment. Trials World Essays Journal, 4,125-136.

Fernandez, G.C.J. (1992) Effective selection criteria for assessing stress tolerance. Proceedings of the International Symposium on Adaptation of Vegetables and Other Food Crops in Temperature and Water Stress, Publication, Tainan, Taiwan.

Fischer, R.A. and Maurer, R. (1978) Drought resistance in spring wheat cultivars. Aust. J. Agric. Res., 29, 897-912.

Forster, P., Ellis, R., Moir, J., Talamè, V., Sanguineti, M .C., Tuberosa, R., This, D ., Teulat-Merah, B., Ahmed, I., Mariy, S. A.E. E., Bahri, H., El Ouahabi, M., Zoumarou-Wallis, N., El-Fellah, M. and Ben Salem, M.(2004) Genotype and phenotype associations with drought tolerance in barley tested in North Africa, Ann. appl. Biol., 144, 157-168.

Gavuzzi, P., Rizza, F., Palumbo, M., Campaline, R.G., Ricciardi, G.L. and Borghi, B. (1997) Evaluation of field and laboratory predictors of drought and heat tolerance in winter cereals. Can. J. Plant Sci., 77, 523-531.

Guendouz, A., Guessoum, S. and Hafsi, M. (2012) Investigation and selection index for drought stress in durum wheat (Triticum durum Desf.) under Mediterranean condition. Electronic Journal of Plant Breeding, 3, 733-740.

Haddadin, M., Abedl-Ghani, A. and Al-Majali, N. (2013) Response of barely cultivars to drought stress imposed at different developmental stages. Jordan Journal of Agricultural Sciences, 9, $507-$ 523.

Haddadin, Maisa'a F. (2015) Assessment of drought tolerant barley cultivars under water stress, International Journal of Agriculture and Forestry, 5, 131-137.

Karami, E., Ghannadha M.R., Naghavi M.R. and Mardi M. (2005) Identifying of drought tolerant cultivars in barley. Iranian J. Agric. Sci., 37, 371- 379.

Kilic, H., Akar, T., Kendal, E. and Saim, I. (2010) Evaluation of grain yield and quality of barley cultivars under rain-fed conditions. African $J$. Biotechnol., 9, 7825-7830.

Mitra, J. (2001) Genetics and genetic improvement of drought resistance in crop plants. Curr. Sci., 80, 758-762.

Muhammad, 1.K., Jaime A.T. and Eurasian H.S. (2012) 
Evaluation of barley genotypes for yielding ability and drought tolerance under irrigated and waterstressed conditions. Agric. Environ. Sci., 12, 287292.

Nazari, L. and Pakniyat, H. (2010) Assessment of drought tolerance in barley genotypes. J. Appl. Sci., 10, 151-156.

Rosielle, A.A. and Hamblin, J. (1981) Theoretical aspects of selection for yield in stress and nonstress environment. Crop Sci., 21, 943-946.

Samarah, H. (2005) Effects of drought stress on growth and yield of barley. Agronomy Sustainable and Development, 25, 145-149.

Shahryari, R. and Mollasadeghi, V. (2011) Introduction of two principle components for screening of wheat genotypes under end seasonal drought. $A d v$. Environ. Biol., 5, 519-522.

Shakhatreh, Y., Kafawin, O., Ceccarelli, S. and Saoub, H. (2001) Selection of barley lines for drought tolerance in low-rainfall. Journal of Agronomy and Crop Science, 186, 119-127.

Sio-Se Mardeh, A., Ahmad, A., Poustini, K. and Mohammadi, V. (2006) Evaluation of drought resistance indices under various environmental conditions. Field Crops Research, 98, 222-229.

Sharafi, S., Ghassemi-Golezani, K., Mohammadi, S., Lak, S. and Sorkhy, B. (2013) Evaluation of barley genotypes (hordeum vulgar l.) by drought tolerance indices and multivariate analysis, J. Bio. Sci., 21,109-122.

Steel, R.G.D., Torrie, J.H. and Deekey, D.T. (1997) Principles and procedures of statistics: " $A$ Biometrical Approach" $3^{\text {rd }}$ ed., McGraw Hill Book Co., Inc. New York.

Subhani, G., Abdullah, M., Ahmad, J., Anwar, J., Hussain, M. and Mahmood, A. (2015) Identification of drought tolerant genotypes of barley (hordeum vulgare 1.) through stress tolerance indices. $J$. Animal Plant Sci., 25, 686-692.

Sultan, M.S., Abdel-Moneam, M.A., Eid, A.A. and Sally E. El-Wakeel (2013) Estimation of some genetic parameters for yield and its components in some hulless barley genotypes under normal and water stress conditions, J. Plant Production, Mansoura Univ., 4, 809-825.

Zare, M. (2012) Evaluation of drought tolerance indices for the selection of Iranian barley (Hordeum vulgare) cultivar. Afr. J. Biotech., 11, 15975-15981.

$$
\begin{aligned}
& \text { تقييم بعض أصناف الثعير المصرية تحت ظروف الإجهاد المائي باستخدام مؤشرات } \\
& \text { تحمل الجفاف والتحليل متعدد المتفيرات }
\end{aligned}
$$

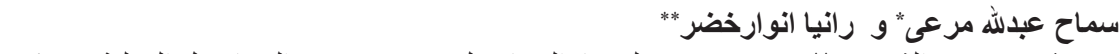

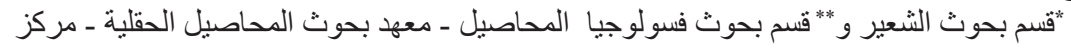

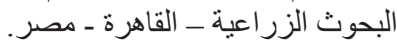

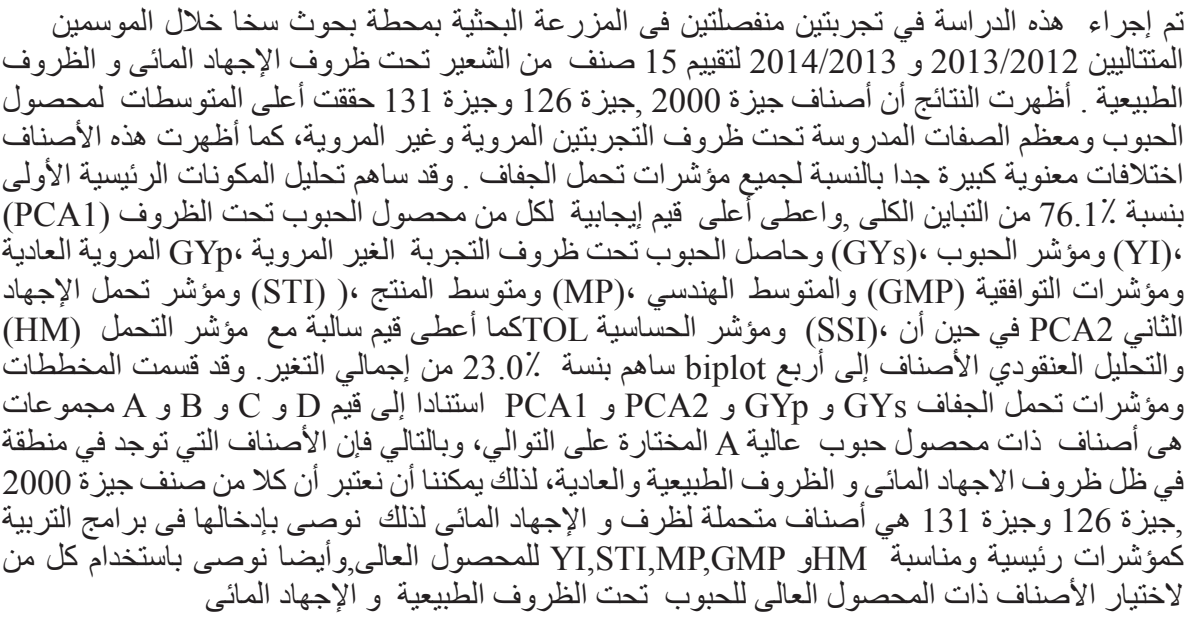

